J. Japan. Soc. Hort. Sci. 54(4) : 490-497. 1986.

\title{
Accumulation of Gas at a Higher Pressure in the Tissues of Stored Cucumber Fruits and Turnip Roots ${ }^{1}$
}

\author{
Ryozo Sakiyama, Masahiro Jimbo ${ }^{2}$ and Shigeo Imada ${ }^{3}$ \\ Faculty of Agriculture, University of Tokyo, Bunkyo-ku, Tokyo 113
}

\begin{abstract}
Summary
Cucumber fruits and turnip roots were harvested and held at $25^{\circ} \mathrm{C}$ with the moisture content which was left decreasing for the first two days but was controlled with little change for the following two days. In both plant organs after two days of storage, the proportion of the total tissue volume occupied by gas space became slightly lower. The mean pressure of gas decreased in cucumber fruits and increased slightly in turnip roots. During the next two days, the gas space developed remarkably in the tissue and the mean pressure of gas rose significantly. These changes were ascribable largely to the accumulation of gas at a pressure of $1.3 \mathrm{bar}$ ( 0.3 bar above an ambient pressure) and above. The gas space was present as bubbles mainly in cells. The volume of both stored organs decreased for the first two days but increased afterwards.

We concluded that the increase in volume of stored cucumber fruits and turnip roots was induced by accumulation of gas under pressure largely in cells. This accumulation of gas was regarded as a cause of further various phenomena concurrently observed in storage such as disappearance of wilting state, a decrease in specific gravity and development of spongy or pithy tissues.
\end{abstract}

\section{Introduction}

An increase in volume of plant tissue is largely attributable to an enlargement of cells caused by the uptake of the water. It can occur in association with growth or in the process of restoration of turgor pressure after wilting. However, Wilkinson (11) showed an increase in volume of stored apple fruit while fresh weight remained constant. He suggested as a possible cause an expansion of intercellular spaces through a rounding off of cell shape due to softening of cell walls.

Sakiyama and Nakamura(7) reported that cucumber fruits showed an increase in volume after having once shrunk while stored under unsaturated vapour conditions. In this case the cells continue to lose water so that the rounding off of cells, which is depen-

1 Received for publication March 14, 1985.

2 Present address: Mitsubishi Shoji, Marunouchi, Chiyoda-ku, Tokyo 100.

3 Present address: Vegetable and Ornamental Crops Research Station, Ano, Mie 514-23. dent on the presence of turgor pressure, cam not occur. Taking into account such coincidental phenomena as disappearance of wilting state and a reduction in specific gravity in those cucumber fruits, it was inferred that the swelling of such fruits is caused by the production of gas spaces, probably in cells, filled with gas at a pressure higher than atmospheric.

Bubbles in cells have been reported for granulated vesicles of Valencia oranges(10) and for pithy roots of radishes(2). These bubbles may be one of the agents giving rise to a higher pressure in cells.

In this paper, mean pressure of gas in post-harvest plant tissues was determined and the volume of gas space was partitioned by pressure in order to show that the accumulation of gas at a higher pressure is related to the enlargement of post-harvest plant organs.

\section{Materials and Methods}

Plant materials and storage conditions

Six fruits of cucumber (Cucumis sativus. 
L., cv. Tokiwa Hikari 3 Go A Gata) of 120 $\mathrm{g}$ mean weight were picked. Two fruits were used for the measurements of parameters before storage. The other four fruits were stored at $25^{\circ} \mathrm{C}$ for two days under unsaturated vapour conditions. Two of them were stored for an additional two days in a polyethylene bag $(0.03 \mathrm{~mm}$ thick) with its opening folded loosely and covered with a moist cloth in order to reduce moisture loss from the fruits. This treatment was undertaken so that the possible changes in the volume and pressure of gas in stored fruits could be shown clearly, separated from those in the water volume. Six roots of turnip (Brassica campestris L., rapifera group, cv. Taibyo Hikari $\mathrm{Kabu}$ ) of $280 \mathrm{~g}$ mean weight were harvested. Their leaves, the unenlarged part of a tap root and fibrous roots were removed. The cut surfaces which were made in removing the former two parts were coated with vaseline. Two roots were used for the measurements of parameters before storage and the other four roots were stored under the the same conditions as the cucumber fruits.

Determinations of parameters of plant materials

At harvest and after two and four days storage, fresh weight, volume and specific gravity of each plant organ were measured, as previously described(6). In cucumber fruits, the middle part of the proximal half of the fruit was taken and the peel and placental parts were removed. A part of the pericarp tissue was weighed and used for determination of a pressure(p)-volume(v) relation of the gas space. After that the tissue was dried at $90^{\circ} \mathrm{C}$ for 3 days and weighed. The difference in weight gave the volume of water in the tissue, assuming the density of water to be $1.0 \mathrm{~g} / \mathrm{cm}^{3}$. Total volume of the tissue was given by fresh weight divided by specific gravity, which was determined on other pericarp tissue

Another part of the pericarp tissue was cut into blocks of $5 \times 5 \times 5 \mathrm{~mm}$. These were soaked in a series of $3 \mathrm{ml}$ mannitol solutions, differing in concentration by $0.01 \mathrm{M}$, at $25^{\circ} \mathrm{C}$. Before soaking and after soaking for one hour, the blocks were blotted and weighed
The solution causing the least change in fresh weight was regarded as being isotonic with the tissue.

The other pieces of the percarp tissue were frozen overnight at $-20^{\circ} \mathrm{C}$ and were then thawed for two hours at room temperature. The juice was extruded, and the lowering of freezing point was measured with a copper-constantan thermocouple. This value, and the isotonic concentration of mannitol were normalized to concentrations of $\mathrm{NaCl}$, which in turn were converted to water potentials in bar, according to the table(4).

The same determinations were carried out in turnip roots, but the tissue used for determination of a $\mathrm{p}-\mathrm{v}$ relation was a wedgeshaped section so that it included both centre and periferal parts of the root. The tissue blocks for determination of the water potential were taken half-way between the core and the outer layer.

Microscopic observations of the tissue were made using fruits and roots which were harvested in different seasons but which were stored in the same way as described above. Fresh tissue was sectioned to approximately $450 \mu \mathrm{m}$ thick.

Determination of a $p-v$ relation and parameters of gas in plant tissue

A $\mathrm{p}-\mathrm{v}$ relation for gas spaces in plant tissues was obtained using an apparatus described elsewhere (5). The apparatus consisted of a capsule fitted with a graduated tube and a pressure chamber in which the capsule was set. Pressure was provided from a nitrogen gas cylinder. The tissue was put in the capsule and the remaining space and the graduated tube were then filled with a previously prepared isotonic mannitol solution.

Pressure in the pressure chamber was raised stepwise and the change of solution level in the graduated tube of the capsule was recorded. The volume was plotted against the reciprocal of pressure. From this $\mathrm{p}-\mathrm{v}$ relation, mean pressure and volume of gas space were estimated and the gas space was partitioned by pressure following the procedure described previously(5).

It was assumed there that the gas in the tissue was composed of an ideal gas and that 
Table 1. Changes in fresh weight, volume and specific gravity in cucumber fruits and turnip roots stored at $25^{\circ} \mathrm{C}$ with the moisture content decreasing over the first two days but changing little over the following two days.

\begin{tabular}{|c|c|c|c|c|c|c|}
\hline \multirow{2}{*}{ Days in storage } & \multicolumn{3}{|c|}{ Cucumber fruits } & \multicolumn{3}{|c|}{ Turnip roots } \\
\hline & 0 & 2 & 4 & 0 & 2 & 4 \\
\hline & & \multicolumn{5}{|c|}{ (relative values) } \\
\hline Fresh weight & 100.0 & 83.1 & 82.6 & 100.0 & 82.0 & 80.5 \\
\hline Volume & 100.0 & 82.2 & 88.2 & 100.0 & 80.7 & 86.9 \\
\hline Specific gravity & 100.0 & 101.1 & 93.7 & 100.0 & 101.6 & 93.0 \\
\hline
\end{tabular}

the whole gas in vapour phase, which might be present in compartmens withw ater at various pressures, dissolved into water completely at the same pressure when the pressure was given to the compartments. This pressure will be referred to as $\mathrm{P}_{\mathrm{d}}$ later. Due to these assumptions the $\mathrm{p}-\mathrm{v}$ curve should be linear when the pressure given to the compartments was increased beyond the original pressure of gas in the compartments. The gas volume becomes 0 at $p_{d}$. However the $\mathrm{p}-\mathrm{v}$ curve obtained experimentally did not show a linear line. In stead the gas volume became 0 asymptotically as reciprocal of given pressure decreased and the curve had an inflection point. Therefore $p_{d}$ was estimated to be the pressure indicated by a point, PD, at which a tangent line drawn at the inflection point crossed the line of 0 volume (Fig. 1). Use of $p_{d}$ estimated in such a manner means that the experimental curve at higher pressures than that of the inflection point was replaced by the tangent line. Thus the estimation of the pressure and volume of gas spaces over these higher pressures is invalid. Mean pressure of the whole gas space was estimated graphically as a pressure of a point, $\mathrm{M}$, at which the tangent line intercepted the line of an original volume.

\section{Results}

During the first two days of storage, both the fresh weight and volume of cucumber fruits and turnip roots decreased, but the specific gravity increased (Table 1). Both fruits and roots developed a flaccid appearance. When stored for an additional two days with their moisture loss prevented, volume increased, specific gravity decreased, and they became firm instead of flaccid.
After four days of storage the freshly cut surface of the pericarp of cucumber fruits looked white and spongy over middle layer of fruit wall, which resembled an incipient

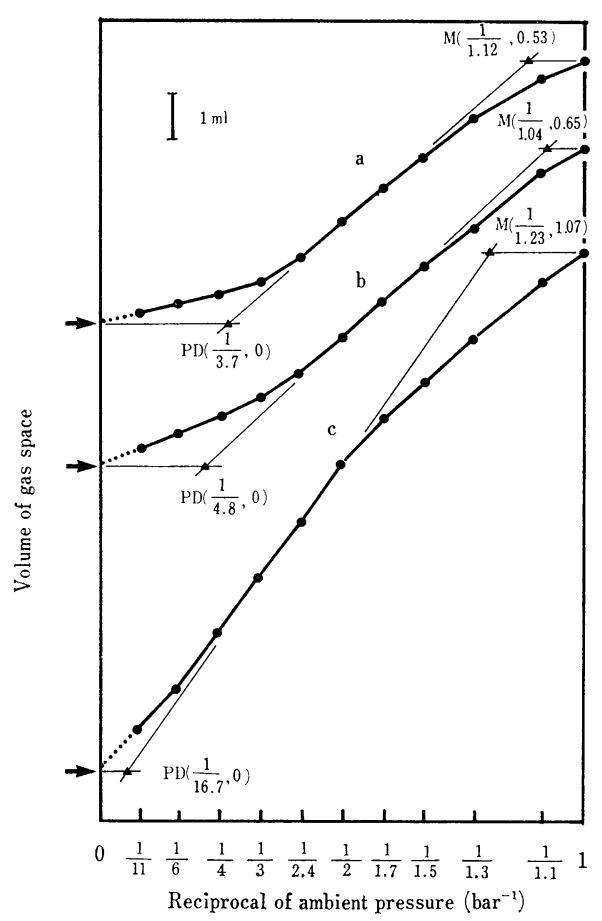

Fig. 1. Volume of gas space plotted against reciprocal of pressure in cucumber fruits (a) at harvest, (b) after storage at $25^{\circ} \mathrm{C}$ for two days with the moisture content decreasing, and (c) after storage for an additional two days with the moisture loss suppressed. Each line is for one of two determinations. $M\left(1 / p_{m}, V\right)$ indicates that $p_{m}$ is the mean pressure of gas in the tissue and $V$ is the volume of the whole gas space. $P D\left(1 / p_{d}\right.$, 0 ) indicates that $p_{d}$ is an estimation of the pressure at which the whole gas is dissolved in the solution. Arrows indicate the estimated point of 0 volume of gas space. 
Table 2. Proportions of the tissue volume occupied by gas or water in cucumber fruits and turnip roots stored at $25^{\circ} \mathrm{C}$ with the moisture content decreasing over the first two days but changing little over the following two days. Values are means of $2 \pm \mathrm{s}$. e.

\begin{tabular}{|c|c|c|c|c|c|c|}
\hline \multirow{2}{*}{ Days in storage } & \multicolumn{3}{|c|}{ Cucumber fruits } & \multirow{2}{*}{0} & \multirow{2}{*}{ Turnip roots } & \multirow[b]{2}{*}{4} \\
\hline & 0 & 2 & 4 & & & \\
\hline & & & $\%$ & & & \\
\hline Gas space & $2.8 \pm 0.2$ & $2.7 \pm 0.0$ & $11.0 \pm 1.6$ & $5.3 \pm 0.5$ & $4.7 \pm 0.8$ & $12.0 \pm 0.3$ \\
\hline Water & $94.0 \pm 0.1$ & $94.0 \pm 0.0$ & $87.4 \pm 1.8$ & $91.2 \pm 0.4$ & $90.9 \pm 1.1$ & $83.3 \pm 0.3$ \\
\hline Residue & $3.3 \pm 0.1$ & $3.4 \pm 0.0$ & $1.6 \pm 0.2$ & $4.1 \pm 0.3$ & $4.5 \pm 0.3$ & $4.8 \pm 0.0$ \\
\hline
\end{tabular}

Table 3. Mean pressure of gas and a difference in water potential $\left(\Psi_{W}\right)$ between the tissue and the juice for cucumber fruits and turnip roots stored at $25^{\circ} \mathrm{C}$ with the moisture content decreasing over the first two days but changing little over the following two days. Values are means of $2 \pm$ s. e.

\begin{tabular}{|c|c|c|c|c|c|c|}
\hline \multirow{2}{*}{ Days in storage } & \multicolumn{3}{|c|}{ Cucumber fruits } & \multicolumn{3}{|c|}{ Turnip roots } \\
\hline & 0 & 2 & 4 & 0 & 2 & 4 \\
\hline & & & bar & & & \\
\hline Mean pressure of gas & $1.12 \pm 0.02$ & $1.04 \pm 0.00$ & $1.18 \pm 0.04$ & $1.09 \pm 0.01$ & $1.12 \pm 0.02$ & $1.21 \pm 0.05$ \\
\hline$\Psi_{W}$ of tissue & $-5.2 \pm 0.4$ & $-6.9 \pm 0.3$ & $-7.5 \pm 0.4$ & $-5.0 \pm 0.4$ & $-7.7 \pm 0.1$ & $-8.6 \pm 0.0$ \\
\hline$\Psi_{W}$ of juice & $-6.6 \pm 0.3$ & $-7.4 \pm 0.3$ & $-6.6 \pm 0.3$ & $-7.2 \pm 0.4$ & $-7.7 \pm 0.1$ & $-7.4 \pm 0.3$ \\
\hline Difference in $\Psi_{W}$ & $1.4 \pm 0.2$ & $0.5 \pm 0.5$ & $-0.9 \pm 0.1$ & $2.3 \pm 0.1$ & $0.0 \pm 0.0$ & $-1.3 \pm 0.3$ \\
\hline
\end{tabular}

stage of pithiness in radishes(2). For turnip root, the white-looking parts were spotted irregularly in one of the two roots after two days of storage, but they developed clearly in two roots after four days, although no cavity due to degeneration of the tissue was found, which was observed typically at an advanced stage of pithiness in turnip roots (9).

The $\mathrm{p}-\mathrm{v}$ relations for gas spaces in cucumber fruit are shown in Fig. 1. Those for turnip root showed a similar pattern (data not shown). Pressure at the inflection point was between 1.7 and 2.4 bar. It was higher after longer storage. In cucumber fruit, $p_{d}$ was 3.6, 4.6, and 20.9 bar after 0,2 and 4 days of storage, respectively and in turnip root $4.2,4.5$ and 9.9 bar. Since $\mathrm{p}_{\mathrm{d}}$ is a function of the ratio of mass of gas and water in a compartment(5), a rise in $p_{d}$ indicates a relative increase in mass of gas.

Total volume of gas space, expressed as percent of the volume of tissue was 2.8 and $5.3 \%$ for cucumber and turnip. This value increased significantly beyond $10 \%$ on the fourth day after a slight decrease on the second day. There was a concomitant reduction in the percent of water volume (Table 2).
Mean pressure of gas in tissue at harvest (Table 3) was slightly higher than atmospheric pressure, about 0.1 bar higher in both plant organs. During storage, mean pres-

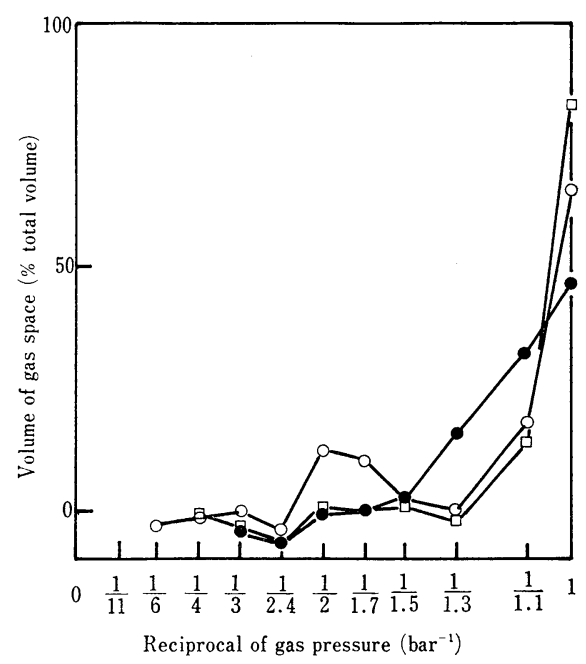

Fig. 2. Volume of gas space partitioned by pressure in the tissues of cucumber fruits, at harvest ( ), after storage for two days at $25^{\circ} \mathrm{C}$ with the moisture content decreasing ( $\square$ ), and after storage for an additional two days with the moisture loss suppressed (O). Values expressed as percent of total volume of gas space are means of the two estimations. 
Table 4. Volume of gas space at three ranges of pressure expressed as proportions of the total volume of gas space in cucumber fruits and turnip roots stored at $25^{\circ} \mathrm{C}$ with the moisture content decreasing over the first two days but changing little over the following two days. Values are means of $2 \pm$ s. e.

\begin{tabular}{lcrrrrr}
\hline & \multicolumn{3}{c}{ Cucumber fruits } & \multicolumn{3}{c}{ Turnip roots } \\
\hline & 0 & 2 & 4 & 0 & 2 & 4 \\
\hline $1.0 \mathrm{bar}$ & & & $\%$ & & & \\
$1.1 \mathrm{bar}$ & $46.9 \pm 1.7$ & $83.2 \pm 2.3$ & $65.5 \pm 2.0$ & $52.5 \pm 1.8$ & $43.6 \pm 2.3$ & $51.2 \pm 6.6$ \\
$1.3 \mathrm{bar}$ and above & $32.8 \pm 4.4$ & $14.2 \pm 4.2$ & $17.9 \pm 5.3$ & $39.5 \pm 0.4$ & $28.1 \pm 9.4$ & $10.7 \pm 0.0$ \\
& $19.9 \pm 2.2$ & $0.9 \pm 1.3$ & $19.9 \pm 5.0$ & $7.8 \pm 0.7$ & $27.2 \pm 7.2$ & $38.5 \pm 5.1$ \\
\hline
\end{tabular}

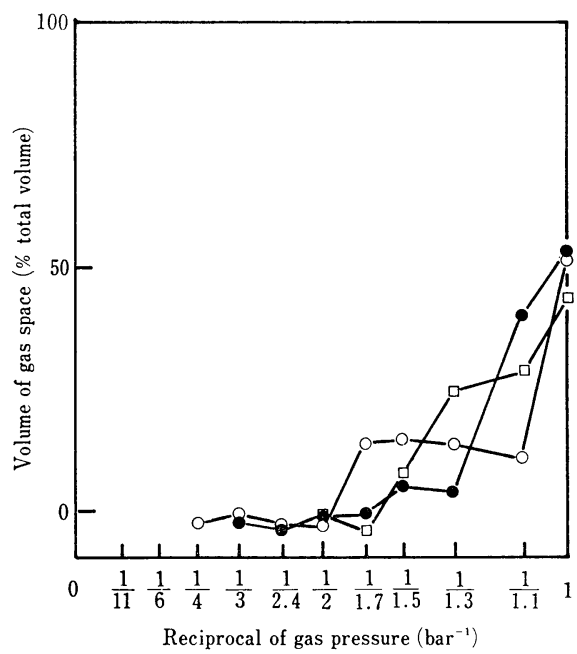

Fig. 3. Volume of gas space partitioned by pressure in the tissues of turnip roots at harvest (•), after storage for two days at 25 ${ }^{\circ} \mathrm{C}$ with the moisture content decreasing (口), and after storage for an additional two days with the moisture loss suppressed (O). Values expressed as percent of total volume of gas space are means of the two estimations.

sure in cucumbers increased after an initial decline, but in turnips it increased continuously. An excess in water potential of the tissue over that of the juice, which could be balanced by a rise in hydrostatic pressure of cells if under conditions of sufficient water supply, was positive only at harvest and was higher than the mean pressure of gas by 1.4 bar in cucumber and 2.3 bar in turnip. In both plants, the difference became little on the second day, compatible with the loss of a turgid appearance, and became negative on the fourth day.

Volume of gas space partitioned by pressure is shown in Figs. 2 and 3. The negative vol- umes computed at the higher pressures beyond the inflection point were also plotted, but they were not large enough to be considered. The highest pressure at harvest was 1.3 bar for cucumber and 1.5 bar for turnip. On the fourth day, the pressure of the gas space was much higher, i. e., 2.0 bar in cucumber and 1.7 bar in turnip.

The volume of gas space at 1.0, 1.1 and $1.3 \mathrm{bar}$ and above (Table 4) were compared. The highest pressure included was the pressure of an inflection point, so that the negative volume of gas space which was obtained over higher pressures was excluded. The volume at 1.0 bar, as expressed by percent of the total volume of gas space, was the largest for both plants and for any days of storage. The gas at $1.3 \mathrm{bar}$ and above in cucumber accounted for about $20 \%$ total gas volume at harvest, disappeared nearly on the second day, but increased significantly on the fourth day. In turnip it continued to increase during storage and occupied $40 \%$ on the fourth day. The volume at 1.1 bar tended to decrease in both plants.

Microscopic observations of the tissue at harvest (Fig. 4 A and D) showed no gas spaces in cells but the shadows due to refraction of incident light indicated the presence of gas in intercellular spaces. This gas space was more clearly observed in turnips on the second day (Fig. 4E), where the boundaries of some intercellular spaces were convex, suggesting the presence of gas pressure. On the fourth day (Fig. $4 \mathrm{C}$ and F) many bubbles were found in cells of both plant parts ; in some cells almost the whole volume was occupied by a bubble. A bubble did not appear to be associated with a special structure of the cells. 


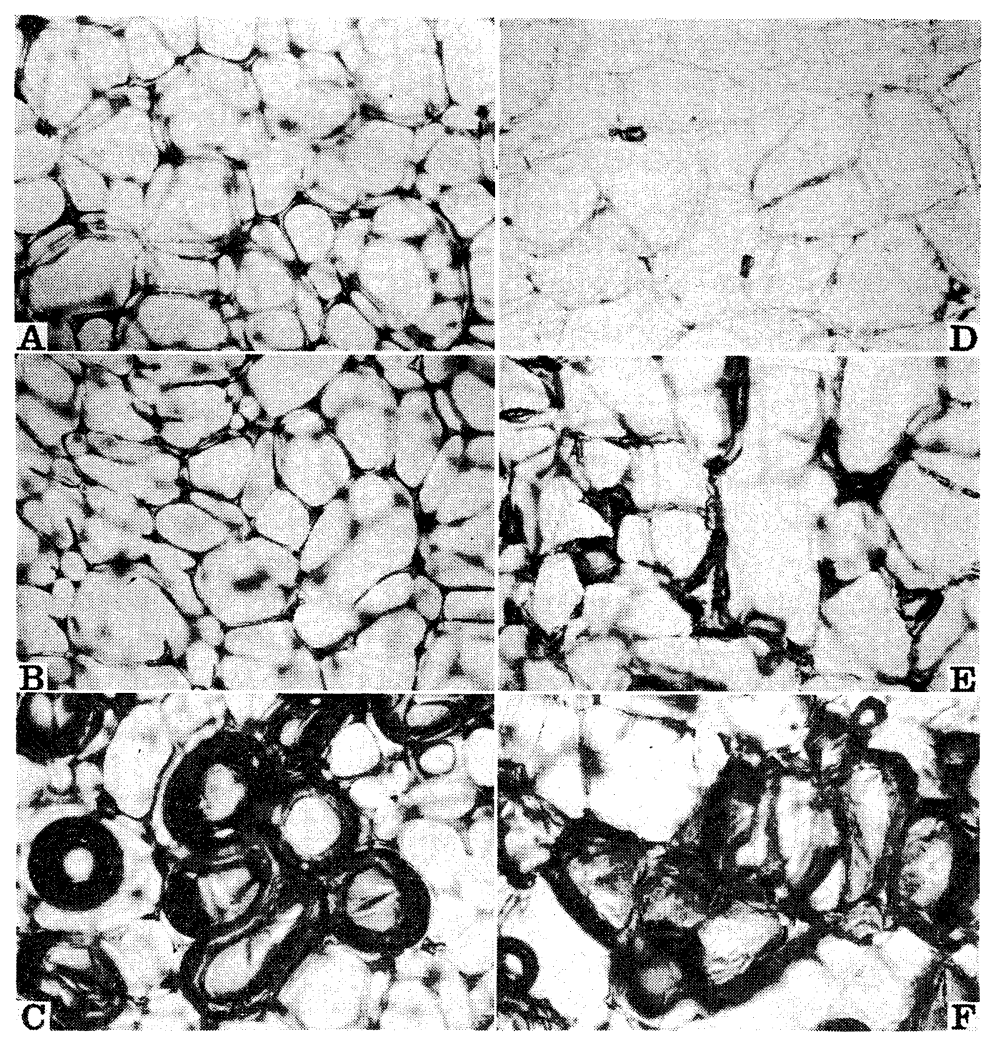

Fig. 4. Light micrographs $(\times 80)$ of tissues of $(A-C)$ cucumber fruit and $(D-F)$ turnip root; ( $A$ and $D$ ) at harvest, $(B$ and $E$ ) after storage for two days at $25^{\circ} \mathrm{C}$ with the moisture content decreasing, and $(C$ and $F$ ) after storage for an additional two days with the moisture loss suppressed.

\section{Discussion}

Pressure of gas in tissues which was higher than atmospheric pressure at harvest decreased when fruits and roots were held with the moisture content decreasing. However during the following two days when moisture loss was almost controlled there were a marked increase in mean pressure and a substantial increase in the proportion of gas space in tissue volume. These indicate that the gas was actively produced until it accumulated in the tissue. The gas thus accumulated was largely present in cells as bubbles so that it could give rise to positive pressure in cells and partly in the intercellular spaces. The gas accumu lating in the cells will have a similar effect to the turgor pressure, in that the wilting state in cucumber fruits and turnip roots disappears. An increase in volume and a decrease in specific gravity, which were shown to be concurrent phenomena, will also occur.

The gas in the intercellular spaces may have a higher pressure, if it is nearly isolated from the atmosphere, e.g., by tightly cemented walls, so that passage of gas does not occur freely. It is probable that the higher pressure observed at harvest in both cucumber fruits and turnip roots is due to the gas in the intercellular spaces, since bubbles in cells were not observed. As the pressure of the gas in the intercellular spaces may be under the influence of turgor pressure of cells, a decrease in mean pressure of gas in cucumber fruits on the second day of storage could be partly due to a lowering of turgor pressure as a result of moisture loss. 
On the fourth day of storage the water potential of the tissue was lower than that of the juice. It indicates that no water in the tissue contributed to the pressure of the cell. It is noted here that the difference in water potential is much larger than can be explained by gas pressure. Thus there must be a factor that reduces water potential along the path between vacuoles and the cell membrane. A decrease in the matric component of water potential in the cytoplasm may have become important in the total water potential of the tissue. However the reason why water movement did not occur as a result of the difference of water potential is not clear. An explanation may be possible that the formation of bubbles or gas space interrupted a rapid movement of water.

It is reasonable to say here that in stored plant organs there are two agents affecting the pressure of cells, i. e., moisture and gas. On the second day of storage turnip roots were soft to the touch, in spite of the rising pressure of gas space. This apparent inconsistency could be the result of a decrease in turgor pressure due to moisture loss which develops over the whole tissue, and an increase in gas pressure, with the latter effect only occurring in restricted parts of root.

Water potential of the juice increased in both plant tissues, in spite of preventing moisture loss. It is possible that this increase was related to the metabolism of cell constituents. In this connection a rise of respiratory activity(6) may have played a role.

The accumulation of gas in the tissue, particularly in cells, of cucumber fruit occurred after detachment from the vine (7), whereas it occurred during growth as well as after harvest in turnip(9). This different behaviour may explain the fact that the gas space at a higher pressure developed earlier for turnip roots than for cucumber fruits. It means that the turnip roots might have been at the stage just before the production of gas space began.

Bubbles in cells are observed at the first stage of granulation of vesicles in Valencia oranges (Citrus sinensis Osbeck, cv. Valen- cia) (10) and at an incipient stage of pithiness in radish (Raphanus sativus L. var. radiculata) roots $(2)$. It is interesting to note that production of bubbles in cells is associated with quality degradation in these crops as well as in cucumber fruits. Development of gas space will make the tissue less juicy. In addition metabolism of cell constituents that may occur in relation to accumulation of gas will make the taste of the tissue flat.

Hardening of the tissue has been reported in relation to granulation of vesicles of Valencia oranges (10), pithiness of roots of long radishes (1), and 'pithy' tissue of cucumber fruits (3). Turrell and Bartholomew(10) attributed the hardening of granulated vesicles largely to gelatin of cell contents accompanied by thickening and transformation in composition of cell walls. From our results, gas at a higher pressure in cells can be another agent.

The tissue which produces gas spaces forms cavities at a later stage lysigenously and called as pithy in turnip or radish roots, and as granulated in Valencia oranges. The tissue in cucumber fruits which became spongy but does not disintegrate is sometimes called as 'pithy' in Japan. Although there are some common symptoms between them, it remained to be investigated whether these disorders were brought about physiologically by the same cause.

\section{Acknowledgement}

We thank Professor M. Iwata for his critical reading of the manuscript and for his encouragement during the study. This work was partly supported by a Grant-in-Aid for Scientific Research from the Ministry of Education, Science and Culture, No. 256022.

\section{Literature Cited}

1. Hagiwara, T. and R. Mozawa. 1951. Pithiness of radishes in the process of drying. Abst. Hort. Assoc. Japan. 1951. 2. (In Japanese)

2. Hagrya, K. 1952. Physiological studies on the occurrence of the "pithy tissue" in root crops. 1. On the process of the occurrence of pithy tissue in company with the growth 
of radish. J. Hort. Assoc. japan. 21:8186. (In Japanese)

3. Hisatake, M., H. Satake and H. Shitomi 1970. Effect of storage conditions on qualities of cucumbers. J. Food Sci. Technol. $17: 204-207$. (In Japanese)

4. LANG, A. R. G. 1967. Osmotic coefficients and water potentials of sodium chloride solutions from 0 to $40^{\circ} \mathrm{C}$. Aust. J. Chem. 20 : 2017-2023.

5. SAKIYAMA, R. 1985. Estimation of the pressure and volume of gas in plant tissues using a pressure chamber. J. Japan. Soc. Hort. Sci. $53: 453-458$.

6. SAKIYAMA, R. and M. JImbo. 1985. Relationship between respiration rate and development of gas spaces in the pericarp of post harvest cucumber Fruit. J. Japan. Soc. Hort. Sci. $54: 242-246$.

7. SAKIYAma, R. and S. NAKAmURA. 1976. Changes in volume and specific gravity of cucumber fruits after harvest in relation to the recovery from a flaccid appearance. Scientia Hortic. $5: 303-310$.

8. SAKIYAMA, R. and S. NAKAMURA. 1980. Volume and specific gravity of cucumber fruits as affected by moisture condition after harvest. Scientia Hortic. 12 : 117-124.

9. ShibuYA, M., Y. SUZUKI and Y. INOUE. 1968. Studies on the occurrence of the pithy tissue in root crops. Memoirs Fac. Agr., Tokyo Univ. Educ. 14:131-188. (In Japanese)

10. TURRELl, F. M. and E. T. BARTHOLOMEW. 1939. Structural and microchemical changes in granulated orange vesicles. Calif. Citrograph. $24: 88$ and 110 .

11. Wilkinson, B. G. 1965 . Some effects of storage under different conditions of humidity on the physiological properties of apples. J. Hort. Sci. $40: 58-65$.

収穫したキュウリ果実及びカブ肥大根組織に和ける気体の蓄積と圧力上昇

\author{
崎山亮三・神保雅弘・ 今田成雄 \\ 東京大学農学部 113 東京都文京区弥生
}

\begin{abstract}
摘要
収穫したキュウリ果実及びカブ肥大根を $25^{\circ} \mathrm{C}$ 下で 2 日間不飽和水分条件下で水分が損失するのにまかせ，そ の後 2 日間高湿条件に移して水分損失をほぼ抑制した. 貯蔵後 $0,2,4$ 日にキュウリ果実の累肉組織, カブ肥大 根組織について組織内気体量や気体圧力を測定した。

組織体積当たりの気体占有体積の割合は両器官とも貯 蔵 2 日後にやや低くなった．気体圧力はキュウリでは低 下し，カブではごくわずかに上昇した．貯蔵 2 日から 4 日にかけては気体占有率が急速に高まり, 気体の平均圧 力も顕著に上昇した. これらの変化には主に大気任より

$0.3 \mathrm{bar}$ 高い気体の蓄積が関与していると考えられた. 蓄積した気体は細胞間腺にも認められたが，ほとんど 細胞内に気泡として観察された.

キュウリ果実やカブ肥大根では収穫後に，一度しおれ てからしばらくすると一見しおれが認められなくなるこ とがあり，またそれに伴って比重が低下したり，器官の 体積が増加したり，またスポンジ状組織や“す’の発達 が観察されることがある. 細胞内に蓄積する圧力の高い 気体はそれらを引き起こす原因とみなしらるものであっ た.
\end{abstract}

